\title{
Obituary
}

\section{Mr. Richard South}

$\mathrm{M}$ R. RICHARD SOUTH was born in July 1846 at Cochran Terrace, Marylebone, the site of which has long since been occupied by the old Great Central Railway. Little is known of his early life beyond the fact that he was educated at a private school at Reading. He died at his home in London on Easter Monday, March 28, after a short illness which terminated a long period of failing health.

The earliest contributions made by $\mathrm{Mr}$. South to the entomological journals, in 1874-78, concerned his captures in the Mill Hill district, Hendon, which appears at that time to have been a very rich locality. Up to 1890 he contributed sixty notes and articles to the Entomologist and the Entomologists' Monthly Magazine, dealing with a great variety of subjects. The most important were his "Contributions to the History of the British Pterophori", published at intervals from 1881 until 1889, which added considerably to existing knowledge of the British plume-moths. He early developed a particular liking for the Microlepidoptera, and many of his notes concern this large group, especially the Tortricidæ; others are faunistic, for example, "The Lepidoptera of the Outer Hebrides, Shetland and Orkneys" (Entom. pp. 25, 28, 98, etc.; 1888); some deal with migration, others with collecting results, variation, etc. His "Notes on the Genus Lyccena" (Entom., pp. 1, 49, 73, 121; 1887), in which the variation of a number of species was described in detail, led him into an acrimonious discussion of the species-concept, upon which his views were somewhat unorthodox. This was not the only matter which brought him into conflict with other lepidopterists of this period, for a year or two earlier, in 1884, in co-operation with those responsible for the Entomologist, he produced a "Synonymic List of the British Lepidoptera". This was designed to act as a label and exchange list and to replace Stainton's, which was long out of date but still the only one available. In the nomenclature used he did his best to apply the law of priority, which necessitated changing a very large number indeed of the names commonly employed-to the very great annoyance of every working lepidopterist of the day. Nevertheless, the list is in constant use even now.

About this time Mr. South's interest in the Microlepidoptera appears to have brought him into touch with John Henry Leech, to whose "British Pyralidæ" (1886) he contributed a number of notes. The association developed, only to be broken by the death of Leech in 1900 . During this period he acted as a kind of curator and adviser to Leech, whose interest in the Far East eventually led to the publication of the "Butterflies of China, Japan and Korea" (18821894), in the production of which all the spade work was done by South. This was supplemented by the publication elsewhere of the descriptions of a very large number of eastern Heterocera new to science. In order to acquire an outlet for this work, Leech purchased the Entomologist in 1890 and appointed South to the editorship, which he retained until 1924. For many years after Leech's death, South continued to work at the Far Eastern fauna, chiefly in collaboration with Wileman, jointly with whom he published a number of papers.

In 1906 there appeared South's " British Butterflies", the first of the three handy little volumes of the Wayside and Woodland Series, which are now standard works on our British Lepidoptera, and have made his name familiar to amateur and professional alike. The volumes on the moths appeared in the following years (1907 and 1908). Although the appeal of these volumes was directed to the beginner, both text and illustrations were so excellent that they at once achieved an immense and deserved popularity, which is not likely to desert them for many years to come. Undoubtedly it is by these volumes and by his long and successful editorship of the Entomologist that Mr. South's name will be remembered amongst British lepidopterists long after those of us who had the pleasure of knowing him as a charming and courtly gentleman, an enthusiastic and painstaking entomologist, an excellent companion, and an honoured personal friend, have passed over where he has so lately gone.

\section{Mr. St. George Lane Fox Pitt}

$\mathrm{By}$ the recent death of Mr. St. George Lane Fox Pitt at his residence in South Eaton Place, at the age of seventy-five years, we lose one of the few remaining pioneers of electric lighting. $\mathrm{He}$ was the second son of Lieut. General A. H. Lane Fox Pitt-Rivers, a distinguished anthropologist and archæologist, who presented his collections to the University of Oxford. In his early days, Lane Fox Pitt (his father took the surnames of PittRivers for himself and that of Pitt for his family) devoted himself to scientific research and mechanical invention. In 1878 he took out a patent for the method of running incandescent lamps in parallel. This patent, being one of the earliest in electric lighting, has been often quoted in the law courts.

$\mathrm{He}$ also took a leading part in improving incandescent lamps. The early glow lamps had carbon filaments in a vacuous glass bulb. These filaments were connected with the mains by 'leading - in' wires passing through the glass. These leading-in wires were made of platinum, which has the same thermal coefficient of expansion as glass. Great difficulty was experienced in connecting the filaments and the platinum wires. The connexion was at first a simple mechanical one, the filaments being merely clamped to the wires. This joint, however, was not satisfactory, as it often worked loose. One of the earliest methods Lane Fox Pitt employed to get over this difficulty was to use a hollow carbon tube into which the platinum wire was inserted.

$$
\text { No. } 3260 \text {, VoL. 129] }
$$


In 1883, Lane Fox Pitt took out an important patent for altering the pressure of electric supply by means of a motor dynamo. This was one of the earliest types of transformer. He was also one of the first to advocate a public supply of electricity from central stations.

Lane Fox Pitt was one of the early active workers in the Society for Psychical Research, and wrote several books on science, philosophy, education, and social problems. $\mathrm{He}$ contested three elections in the Liberal interest, but without success. He married, in 1899, Lady Edith Douglas, daughter of the eighth Marquess of Queensberry.

WE regret to announce the following deaths:

Prof. W. R. Dron, Dixon professor of mining in the University of Glasgow since 1923, on April 16, aged sixty-three years.

Sir Patrick Geddes, formerly professor of socio- logy and civics in the University of Bombay and of botany at University College, Dundee, who was well known for his work for education and the study of sociology, aged seventy-eight years.

Dr. Alfred Hay, sometime professor of electrotechnology, Royal Indian Engineering College, Coopers Hill, and afterwards at the Indian Institute of Science, Bangalore, on April 13, aged sixty-six years.

Prof. G. M. Robertson, professor of psychiatry in the University of Edinburgh, and physician superintendent of the Royal Edinburgh Hospital for Mental and Nervous Disorders, on March 28, aged sixty-eight years.

Mr. Eustace Short, of the firm of Short Brothers, of Rochester, who was a pioneer in the design and construction of aeroplanes, on April 8, aged sixtytwo years.

Prof. A. L. Urquhart, O.B.E., professor of pathology at the University of Cairo, on March 28.

\section{News and Views}

\section{In Honour of Darwin}

ON April 19, 1882, science sustained an irreparable loss by the death of Charles Darwin in his seventyfourth year. On April 26 of that year his mortal remains were borne on the shoulders of his comrades to his last resting-place at Westminster Abbey, where they were laid close beside the graves of Sir John Herschel and Sir Isaac Newton. At the end of last year we commemorated the centenary of the start of Darwin's famous voyage in the Beagle; three years after his return he married, and in 1842 settled at Downe, Kent. It is no exaggeration to say that the work which emanated from that quiet English home during the succeeding forty years proved more effectual than any other in making the nineteenth century illustrious. The general facts upon which the principle of evolution by natural selection is based - the struggle for existence, survival of the fittest, and heredity-were all well known before Darwin's work. His claim to everlasting memory rests upon the many years of devoted labour whereby he tested the idea in all conceivable ways, amassing facts from every department of science, balancing evidence with the soundest judgment, and at last astonishing the world as with a revelation by publishing the completed theory of evolution by natural selection. Of very few men in the history of our race can it be said that they not only enlarged science but also changed it, not only added facts to the growing structure of new knowledge but also profoundly modified the basal conceptions upon which the whole structure rested: and of no one can this be said more truly than of Charles Darwin. It is a striking tribute to his memory that April 19 was declared a public holiday in the U.S.S.R. in honour of the author of the "Origin of Species ".

\section{Research Scholarships at the Royal College of Surgeons}

Aт a meeting of the Council of the Royal College of Surgeons of England on April 14, the president of the
College, Lord Moynihan, announced an important benefaction from the trustees of the late Viscount Leverhulme. In presenting $£ 1000$ to provide "Leverhulme Scholarships" in surgical research, the trustees expressed the hope of being in a position to make a similar donation from year to year. The gift thus announced permits the Council of the College to go forward with an ambitious scheme of experimental research made possible by the munificence of Sir Buckston Browne, who a year ago gave $£ 100,000$ to build, equip, and endow a Research Farm at Downe, Kent. The Buckston Browne Research Farm, which is approaching completion, has been built on land which adjoins the home and grounds of Charles Darwin, which Sir Buckston acquired in 1928 and conveyed to the British Association, to be maintained as a memorial of Darwin and to be used for the advancement of science. The Leverhulme Scholarships are to be given to aid young men and women who are selected by the Council of the College to investigate surgical problems at the Buckston Browne Research Farm. Besides the laboratories at Downe, the Council has also equipped laboratories in the College, Lincoln's Inn Fields. These are now fully occupied. Lord Moynihan succeeded in obtaining temporary scholarships for men working in the College laboratories from Sir Bernhard Baron, Lord Beaverbrook, and the late Lord Melchett. The Council also sets aside annually from its own funds $\mathfrak{£ 5 0 0}$ to provide a College fellowship in surgical research.

\section{Australian Observatories}

Fon reasons of economy, the Australian Premiers Conference has decided that there shall in future be only two national observatories instead of the existing five (Perth, Adelaide, Melbourne, Sydney, and Canberra). The total saving cannot be great, since the combined revenues of all five from governmental sources amount to less than $£ 15,000$ per annum: nevertheless, three are to be closed. The Premiers Conference has asked Sir Thomas Lyle, Dr. A. C. D. 